\title{
SISTEM INFORMASI PEMBAYARAN PREMI SEMPROT PADA PTPN IV UNIT KEBUN LARAS SERBELAWAN KABUPATEN SIMALUNGUN
}

\author{
Agung Nizhar ${ }^{1}$, Dedi Suhendro², Ryan Jaya Julio M. T P 3 \\ Program Studi Komputerisasi Akuntansi \\ AMIK Tunas Bangsa Pematang Siantar \\ Agungnizhar050599@gmail.com ${ }^{1}$ \\ Dedi.su@amiktunasbangsa.ac.id ${ }^{2}$
}

\begin{abstract}
Abstrak
Abstrak - Kemajuan Ilmu Pengetahuan dan Teknologi saat ini sangat berperan penting dalam kehidupan manusia dalam mengerjakan atau menyelesaikan suatu aktivitas perkerjaan sehari-hari, Khususnya dalam pembayaran Premi semprot yang diterapkan pada PTPN IV Unit Kebun Laras Serbelawan Kabupaten Simalungun, disini Penulis Membuat sebuah system informasi pembayaran premi Sempot Pada PTPN IV Unit Kebun Laras dengan Bahasa Pemrograman Microsoft Visual Studio 2010 dengan databaseMySql. Oleh karena itu dengan adanya sistem yang dirancang oleh penulis dapat meminimalisir kesalahan yang terjadi dalam pembayaran premi sempot dan dapat mengoptimalkan secara efektif dan efisien.
\end{abstract}

Kata Kunci : microsoft visual studio 2010, database mysql, pembayaran premi semprot, sistem informasi

\section{Pendahuluan}

Kebutuhan karyawan diusahakan dapat terpenuhi melalui pekerjaannya. Apabila seorang karyawan sudah terpenuhi segala kebutuhannya maka dia akan mencapai kepuasan kerja dan memiliki komitmen terhadap perusahaan. Perusahaan adalah semua jenis kegiatan yang berbentuk usaha dengan atau tanpa badan hukum, yang menggunakan atau mempekerjakan karyawan/pekerja. Pembayaran Premi sebenarnya merupakan salah satu syarat perjanjian kerja yang diatur oleh pengusaha dan 
karyawan atau karyawan serta pemerintah. Tujuan dari penelitian ini adalah untuk mengidentifikasi sistem Pembayaran premi, jaminan yang diterima karyawan serta untuk menganalisis tingkat kepuasan karyawan perkebunan terhadap sistem pembayaran premi di PT. Perkebunan Nusantara IV Unit Kebun Laras.

\section{A. Defenisi Sistem}

Menurut (Purnamasari, 2013) Sistem merupakan kumpulan elemen yang saling berhubungan satu sama lain yang membentuk satu kesatuan dalam usaha mencapai suatu tujuan. Di dalam perusahaan, yang dimaksud elemen dari sistem adalah departemen-departemen internal, seperti persediaan barang mentah, produksi, persediaan barang jadi, promosi, penjualan, keuangan, personalia; serta pihak eksternal seperti supplier dan konsumen yang saling terkait satu sama lain dan membentuk satu kesatuan usaha.

Menurut (Erinawati, 2012) Sistem adalah gabungan suatu objek yang mempunyai hubungan baik dari segi fungsi maupun hubungan tiap-tiap ciri-ciri objek yang dengan keseluruhan menjadi kesatuan yang mempunyai fungsi.

Menurut (Irawati, n.d.) Sistem adalah kumpulan beberapa unsur dimana unsur tersebut saling berkaitan bersama dan beroperasi dalam mencapai suatu tujuan yang sama.

\section{B. Informasi}

Menurut (Miyarso, 2015) Informasi adalah hasil pemrosesan data yang diperoleh dari setiap elemen sistem tersebut menjadi bentuk yang mudah dipahami dan merupakan pengetahuan yang relevan yang dibutuhkan oleh orang untu menambah pemahamannya terhadap fakta-fakta yang ada.

Menurut (Rani Puspita, 2008) Informasi adalah data yang diolah menjadi bentuk yang berguna untuk membuat suatu keputusan.

Menurut (Suhendro, 2017) Informasi adalah suatu data yang telah diolah menjadi bentuk yang memiliki arti bagi si penerima dan bermanfaat bagi pengambilan keputusan saat ini atau mendatang, informasi juga sangat bermanfaat bagi pembuatan keputusan bisnis dan ekonomis oleh investor yang ada dan yang 
potensial, kreditor, manajemen, pemerintah dan pengguna lainnya.

\section{Defenisi Pembayaran}

Menurut (Hidayati, 2013) Pemabayaran adalah mekanisme yang digunakan untuk melaksanakan pemindahan dana guna memenuhi suatu kebutuhan ataupun kewajiban yang timbul dari kegiatan ekonomi.

Menurut (Cucus, n.d.) Pembayaran adalah suatu sistem yang berkaitan dengan pemindahan sejumlah nilai uang dari stu pihak ke pihak yang lain.

\section{Defenisi Premi}

Menurut (Putu P, Suryawati C, 2009) Premi adalah sejumlah uang yang harus dibayarkan setiap bulannya sebagai kewajiban dari tertanggung atas kesertaanya di suatu perusahaan, dengan memperhatikan keadaan-keadaan yang tertanggung.

Menurut (Miyarso Dwi Ajie, n.d.) Premi adalah suatu seperangkat mekanisme yang digunakan untuk melaksanakan pemindahaan dana guna memenuhi suatu kewajiban yang timbul dari suatu kegiatan ekonomi.

Menurut (Irawati, n.d.) Premi adalah hadiah atau uang dan sebagainnya yang diberikan sebagai perangsang untuk meningkatkan prestasi kerja, atau junmlah uang jumlah uang yang harus dibayarkan pada waktu tertentu.

\section{Metode Penelitian}

Dalam penelitian ini, peneliti menggunakan beberapa metode dalam mengumpulkan data yaitu :

a. Rancangan Menggunakan Data Flow Diagram Level 0

Rancangan proses dimodelkan dengan Data Flow Diagram(DFD). Perancangan DFD merupakan hal yang harus dilakukan karena dengan melihat DFD maka kita akan mengetahui arus data yang mengalir dalam suatu sistem dan mengimplementasikannya pada sebuah database. Dapat dilihat pada gambar 1. 


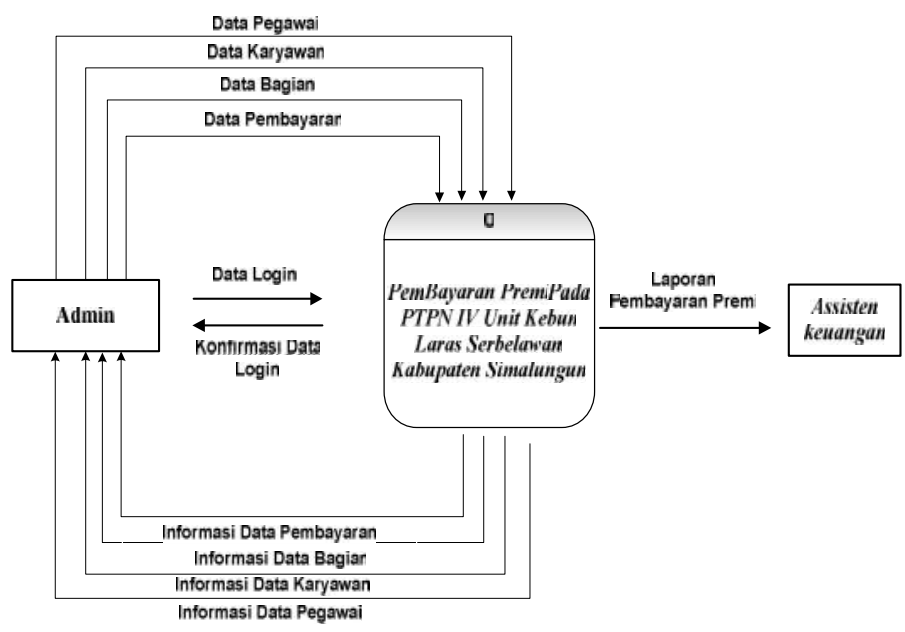

Gambar 1. DFD Level 0

Alat analisa yang digunakan adalah flowchart (bagan alir) merupakan respfestasi secara grafik dari satu algoritma atau prosedur untuk menyelesaikan suatu masalah. DFD (Data Flow Diagram) adalah suatu diagram yang menggunakan notasi i untuk menggambarkan arus data sistem yang penggunaanya sangat membantu untuk memahami secara logika, terstruktur, dan jelas. Implementasi program menggunakan bahasa pemrograma visual basic Net, yang merupakan program yang dikembangkan secara bersama para programer.

b. Mengunakan Entity Relationship Diagram (ERD)

Bentuk ERD (Entity Relational Diagram) dari data Pembelian Pada PTPN IV Unit KebunLaras Serbelawan Kabupaten Simalungun diperlihatkan pada gambar 2 . 


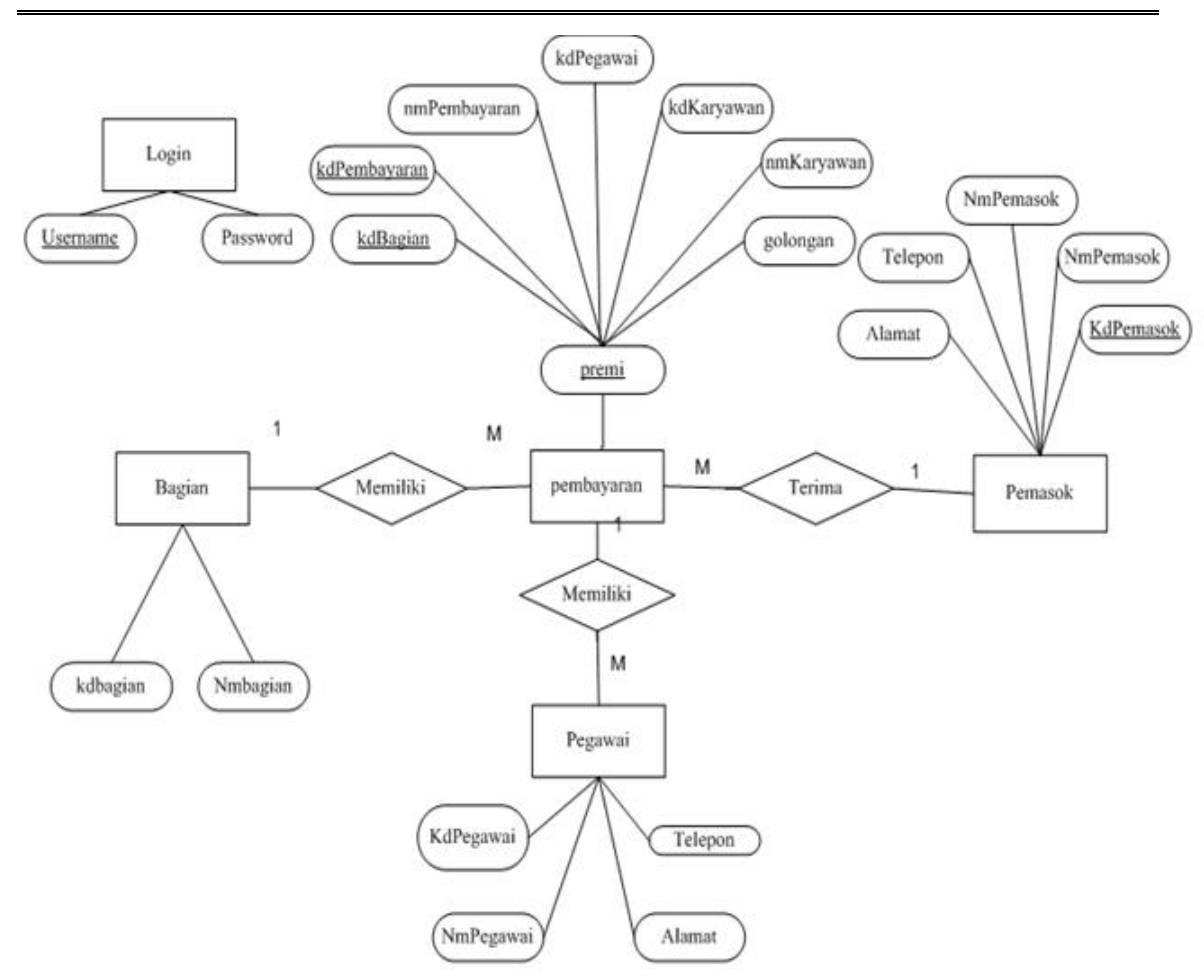

Gambar 2. Entity Relational Diagram

c. Relasi Antar Tabel (RAT)

RAT berguna sebagai gambaran hubungan antara tabel dimana tabel yang mempunyai relasi dapat saling berkomunikasi. Relasi antar tabel dapat dilihat pada gambar 3. 


\section{Yo rembayan premi to_login \\ Q Username : varchar(20) \\ 1) Fassinord varc ari 20$)$}

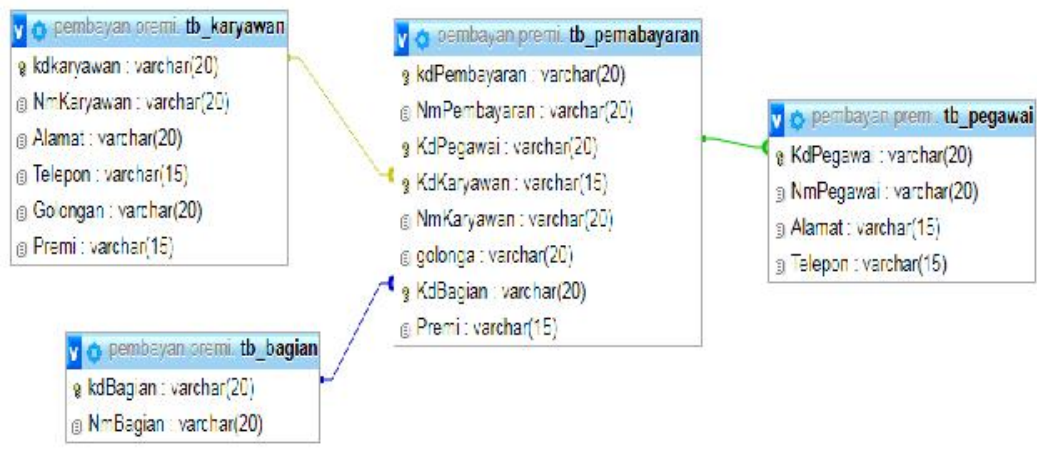

Gambar 3. Relasi Antar Tabel

\section{Pembayaran}

Pemabayaran adalah mekanisme yang digunakan untuk melaksanakan pemindahan dana guna memenuhi suatu kebutuhan ataupun kewajiban yang timbul dari kegiatan ekonomi (Hidayati, 2013).

\section{Defenisi Premi}

Premi adalah sejumlah uang yang harus dibayarkan setiap bulannya sebagai kewajiban dari tertanggung atas kesertaanya di suatu perusahaan, dengan memperhatikan keadaan-keadaan yang tertanggung (Putu P, Suryawati C, 2009).

Berikut ini adalah jenis-jenis pembayaran premi karyawan lapangan yang digunakan pada PTPN IV Unit Kebun Laras Serbelawan adalah sebagai berikut:

1. Premi Menurunkan Rayutan.

2. Premi Semprot SCUD.

3. Premi Menyemprot Apogina.

4. Premi Langsir Air Semprot SCUD.

5. Premi Langsir Air Semprot Mucuna Dipiringan.

6. Premi Langsir Air Semprot Piringan. 
7. Premi Khemis Mucuna TM-1.

8. Premi Langsir Air Khemis Piringan TM.

9. Premi Langsir Air Khemis Mucuna TM 1.

10. Premi Mupuk.

\section{Hasil dan Pembahasan}

Pembangunan form pada tulisan ini dibuat dengan bahasa pemrograman Visual Basic .Net 2010. Sistem yang sudah dirancang selanjutnya akan diteruskan ke tahap pengimplementasian sistem. Berisikan hasil atau tampilan dari menu, halaman masukan(Input sistem) dan laporan (Output sistem).

\section{Form Login}

Fungsi Login untuk pengguna dapat masuk dan mengakses program setelah dilakukan validasi yang biasanya berupa username dan password.

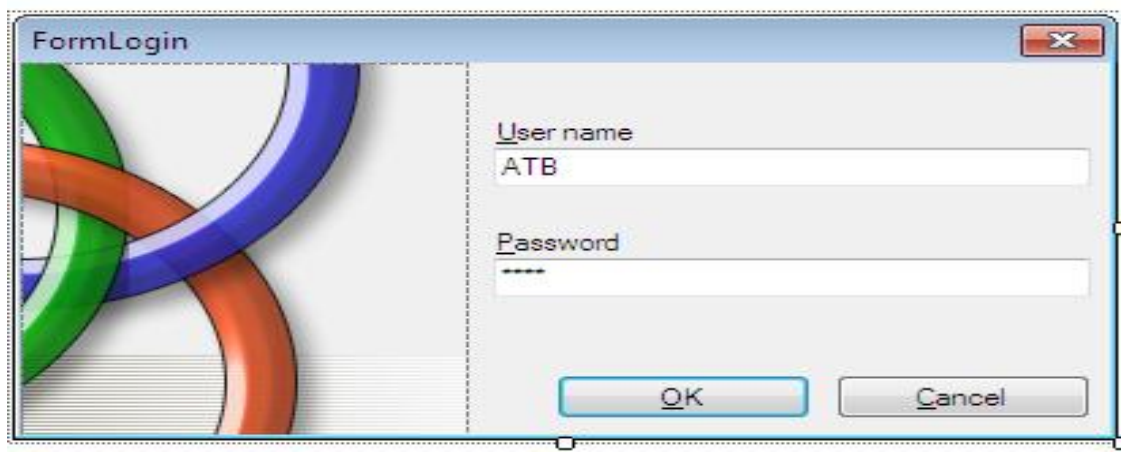

Gambar 4. From Login

Gambar diatas merupakan form login password, password yang dimasukan minimal 5 karakter. Setelah itu pilih Ok untuk melanjutkan.

\section{Masukan (input)}

Dibawah ini adalah gambaran dari rancangan masukan (input) Perancangan Sistem Pembayaran Pestisida Pada PTPN IV KebunLaras. 
Adapun spesifikasi rancangan pembayaran premi adalah sebagai berikut:

Nama pegawai : Leni Siahaan

Fungsi : Untuk melihat Data Masuk

Media : Kertas

Distribution : Asisten Keuangan

\section{Rancangan Keluaran (Output)}

Dibawah ini adalah gambaran dari rancangan keluaran (output) Perancangan Sistem Pembayaran Premi karyawan lapangan Pada PTPN IV KebunLaras.

\section{LOGO Laporan Pemabayaran Premi Semprot Pada PTPN IV KEBUN LARAS}

\begin{tabular}{|l|l|l|l|l|l|l|}
\hline \hline No & Nama Pegawal & Jenis Kelamin & Alamat & Jumıan Harı Kerja & Premi Perharı & Total \\
\hline & & & & & & \\
& & & & & & \\
\hline
\end{tabular}

Laras, DD/MM $/ Y Y$

\section{Gambar 5. Form Rancangan Keluaran}

Adapun spesifikasi rancangan keluaran adalah sebagai berikut:

Nama Keluaran : Laporan Pembayaran Premi

Fungsi : Untuk melihat laporan Data

Pembayaran Premi

Media

: Kertas

Distribusi

: Ditujukan kepada Asisten Keuangan

\section{Kesimpulan}

Dengan adanya sistem yang telah dibuat oleh penulis dapat membantu para pegawai (staff) dalam melakukan pembayaran premi karyawan lapangan agar lebih terorganisir dan lebih baik 
dalam melakukan membayar dan memberikan keuntungan bagi para staff dalam memberikan pembayaran premi tiap bulanya. Sistem ini hanya dibuat pada PTPN IV UNIT KEBUN LARAS SERBELAWAN KABUPATEN SIMALUNGUN. 


\section{Daftar Pustaka}

Cucus, A. (n.d.). Perancangan Sistem Informasi Klaim Asuransi Jiwa Menggunakan Ms.Visual Basic 6.0. pada PT.Asuransi Jiwaraya Kota Bandar Lampung. Perancangan Sistem Informasi Klaim Asuransi Jiwa Menggunakan Ms.Vsual Basic 6.0. Pada PT. Asuransi Jiwarasraya Kota Bandar Lampung, 31-35.

Erinawati, H. D. (2012). Pembangunan Sistem Informasi Pembayaran Sekolah Pada Sekolah Menegah Atas (SMA)

Negeri 1 Rembang Berbasis Web. Pembangunan Sistem Informasi Pembayaran Sekolah Pada Sekolah Menegah Atas (SMA) Negeri 1 Rembang Berbasis Web, 4, 40-46. https://doi.org/10.3112/speed.v4i4.1090

Hidayati, R. N. (2013). Komputerisasi Pengolahan Data Penerimaan, 10(2), 129-135. Komputerisasi Pengolahan Data Penerimaan Peserta Didik Baru Di SMK Negeri 3 Pati Berbasis Intranet, 5, 35-41.

Irawati, A. (n.d.). Proses pembuatan susu bubuk formula di PT. Sari Husada unit II Kemudo Klaten.

Miyarso Dwi Ajie. (n.d.). Sistem informasi Konsep dasar.

Purnamasari, T. (2013). Pembangunan Sistem Informasi Pengolahan Data Pegawai Dan Penggajian Pada Unit Pelaksana Teknis Taman Kanak-Kanak Dan Sekolah Dasar Kecamatan Pringkuku. Pembangunan Sistem Informasi Pengolahan Data Pegawai Dan Penggajian Pada Unit Pelaksana Teknis Taman Kanak-Kanak Dan Sekolah Dasar Kecamatan Pringkuku, 5, 1-6.

Putu P, Suryawati C, P. S. (2009). Persepsi Stakeholders Terhadap Latar Belakang Subsidi Premi, Sistem Kapitasi Dan Pembayaran Premi Program Jaminan Kesehatan Jembrana. Persepsi Stakeholders Terhadap Latar Belakang Subsidi Premi, Sistem Kapitasi Dan Pembayaran Premi Program Jaminan Kesehatan Jembrana, 12, 33-40. 
Rani Puspita, M. Y. (2008). Sistem Informasi Aplikasi Virtual LAB pada Laboratorium Sistem Informasi Universitas Gunadarma. In Proceeding, Seminar Ilmiah Nasional Komputer dan Sistem Intelijen (KOMMIT) (pp. 190-198).

Suhendro, D. (2017). Analisis Profitabilitas dan Likuiditas Untuk Menilai Kinerj[a Keuangan Pada Pt Siantar Top Tbk. Human Falah, $4(2)$, 218-235. https:// doi.org/10.1016/j.oooo.2016.12.001 